\title{
Information skills and library knowledge for higher education teachers
}

\section{Tatiana Sanches}

UIDEF, Instituto de Educação, Universidade de Lisboa, Portugal.

\begin{abstract}
The explosion of information, not only in print, but in a digital context has become a fertile area for exploring, transmitting, and disseminating information, enabling learning and teaching, transforming and creating new knowledge. Higher education teachers need to be aware of how to train and guide their students in multiple ways to knowledge, including the ability to deal with information in print and digital contexts, so information literacy training should be a priority. This paper aims to list the skills to be developed by these teachers, preferably integrated into their professional development. Starting from the framework of tried-and-tested models, a flexible and comprehensive content structure is proposed, considering the need for their transfer to students. The importance of collaborative work with higher education libraries is stressed.
\end{abstract}

Keywords: Higher education; Teaching skills; Information Literacy; Information Skills; Academic libraries. 


\section{Introduction}

On November 11, 1997, UNESCO issued the Recommendation concerning the status of higher education teaching personnel (UNESCO, 1997) which addressed the main definitions and concepts of the area, guiding principles, objectives and educational policies that should frame it. This recognized that advances in higher education are based on the qualifications and knowledge of higher education teachers, as well as their human, pedagogical and technical qualities, supported by academic freedom, professional responsibility, collegiality, and institutional autonomy. In Portugal, the Portuguese Education System's Basic Law establishes three areas: research, the understanding of the world and the dissemination of culture and the training of professionals (Esteves, 2011). These three areas have been competing for the attention and interest of teachers, in a somewhat contradictory or even competitive way. Higher education teachers' education emerges under various organizational modalities around the globe: postgraduate training, whether or not integrated into basic training, optional or compulsory training, more focused on pedagogical aspects or distributed over different themes (Aramburuzabala, Hernández-Cesario, Castilla, Angel-Uribe, 2013; Ó, Almeida, Viana, Sanches, Paz, 2019). Zabalza (2007) addressed the importance of competences in higher education teacher, synthetically organized around knowledge (disciplinary contents to be taught and related teaching-learning processes), specific skills (communication, didactics, assessment) and teachers' attitudes as trainers (availability, empathy, intellectual rigor, professional ethics, among others). More recently Rivilla, Cabezas, Navío, and Domínguez (2019) list some of the skills required of university teachers, and highlight planning, communication, digital / media design, assessment, innovation, and research. They detailed that continuous updating is fundamental, namely in the research processes that involve the updated knowledge of bibliography and the reading and consultation of scientific articles. In the wake of these goals, Peres, Miranda, Simeão (2015, p. 219) highlighted the importance of preparing students and teachers for "access, creative use of information in various media, promoting the strategic use of basic knowledge in academic tasks". Silva and Farias (2019) also focus on the competences to be developed by higher education teachers: in the supervision chapter it is urgent to master a series of competences to provide effective support to their students, namely "bibliographic search, readings, debates, collection of data, written production, seminar presentations, etc.", that require the mobilization of "a set of knowledge, skills, and attitudes related to an effective interaction with information that makes it possible to solve problems and make decisions", sustaining information skills (Silva \& Farias, 2019, p. 52). Analyzing the perspective of the advisors regarding the informational skills needed to carry on the research work, they conclude that the advisors consider as fundamental in the research process those concerning the "recognition of information sources that make it easier to search, besides the correct use information" (Silva \& Farias, 2019, p. 65). 


\section{Aligning information literacy with teaching and learning}

Student-centered learning requires the use of learning resources based on print, digital and multimedia information. Digital libraries, databases, and repositories facilitate the reuse of research content, providing access to a variety of sources and enhancing the formation of critical thinking and the creation of more complex ideas while encouraging students to use resources, and reinterpret them (McGill, 2017). To develop all these skills, information literacy is used, a theoretical-practical construct that involves the skills to handle information appropriately and meaningfully, particularly within the academic context. The concept (ALA, 2000) explains that a skilled person with information skills should be able to determine the need for information and its extent, access information efficiently and effectively, evaluate information and its sources critically, incorporate selected information into its knowledge base, use information effectively to meet a specific objective, understand the economic, legal and social implications surrounding the use of information and knowhow to access and use it, ethically and legally. More recently the concept has been updated. In 2016, the Association of College and Research Libraries (ACRL, 2016) adopted the Framework for Information Literacy for Higher Education. Product of intense work to redefine the content and skills required to handle information adds reflective discovery of information, which comprises how information is produced and valued by using it ethically and legally, creating new knowledge. In this framework, six conceptual frames are introduced, representing broad ideas applicable to different academic disciplines (ACRL, 2016; Fisher, 2017; Swanson, 2017): Authority Is Constructed and Contextual; Information Creation as a Process; Information Has Value; Research as Inquiry; Scholarship as Conversation; Searching as Strategic Exploration. In the context of higher education, the need to develop information literacy skills is unavoidable, given the underlying objectives of this level of education (Lopes, Sanches, Andrade, Antunes, Alonso-Arévalo, 2016). One of the main challenges of teachers is the awareness of their role in guiding the careful selection of information, which is based on the development of critical thinking (Cruz, Nascimento \& Dominguez, 2019). It is from the awareness of the social environment and their personal and professional capacities that teachers must act, transmitting knowledge while developing students' research skills, promoting better learning, investing in the teaching of research strategies, contributing for the ethical and informed use of knowledge and inducing authorship and communication experiences in the students. Thus, it is legitimate to consider information literacy as a fundamental competence for teachers. This outlook is not new (see, for example, Ödalen, Brommesson, Erlingsson, Karlsson \& Fogelgren, 2019; Sanches, 2017; Schrum, Niederhauser, Strudler, 2016). Student mentoring and supervision often includes tutoring for their research, and close monitoring of the student during the preparation of his academic work, involving research and in-depth use of information. Shipman, Bannon, and Nunes-Bufford (2015) relate in-service teachers' information seeking and use habits with 
previous training, thus stating that the results of information literacy training are persistent, accompanying teachers throughout their professional performance. There is thus a recognition of the importance of information literacy as competence to be integrated into the training of teachers, trainers, and educators. This is expressed not only in the report of experiences and studies such as those mentioned, but also in the further questioning of interveners, and in the theoretical reflections that this theme has triggered. Godbey's (2018) practical study is an example that focuses on improving the literacy proficiency of future teachers. Perzycka (2015) theoretic reflexion underlies the importance of the study and application of information literacy in a more consistent way, from the deep analysis of the conditions that constitute it, as well as from the dialogue with theory, from which practices can benefit. The inspiring work of Maybee, Bruce, Lupton \& Pang (2018) explains curriculum design whose contents are intertwined with intentional involvement with information. Although higher education teachers may use information in sophisticated ways to teach their subjects, maybe they are not used to teach students to use information creatively and reflexively in academic work. This is also the role of teachers in soaking information literacy in their teaching programs.

\section{Study description}

Observation of previous studies supports the integration of information skills in the curriculum of higher education teachers. The reflection thus aims to highlight the impact of information literacy on the educational and learning context, analyzing paths to be explored by teachers. In this line of thought, Cowan and Eva (2016) show that by equipping higher education teachers with tools and skills to teach their students' information literacy more holistically, it encourages them in their teaching tasks, and research. Communicating, encouraging, educating and infiltrating information literacy are multifaceted contributions to meeting the needs of teachers, and this approach is advantageous in that it contributes significantly to moving from gathering information to creating knowledge.

The University of Lisbon is the largest Portuguese University. Located in the capital, it brings together 18 Schools (Colleges and Institutes) and serves a population of about 50,000 students, with nearly 3,500 teachers and 2,500 staff. This large university has teaching and research areas in autonomous units. The Institute of Education is one of the schools, dedicated to research and education, in education and training in Portugal, and currently has about 900 students. Institutional defies include innovation in the teaching and learning process.

\subsection{Objectives}

In line with the competencies required of teachers and the new principles of information literacy in conjunction with academic writing, we sought to design a curriculum proposal integrated into a Postgraduate Degree in Pedagogy of Higher Education, taught by the 
Institute of Education of the University of Lisbon. The proposal is based on a reflection on the importance of academic writing as a result and product of intellectual reflection and the use of information. It is therefore intended to support teachers in guiding students towards the pursuit of their work, from research to publication, particularly using information literacy.

\subsection{Methods}

A discipline was designed, framed in the Postgraduate Pedagogy of Higher Education, offered in the academic year 2019/2020 at the Institute of Education of the University of Lisbon, concerning the theoretical-conceptual framework of the ACRL Framework. The objective was to develop and update the skills related to knowledge of tools and strategies for dealing with information through the exercise of academic writing. The process aimed to incorporate learning activities, tasks and assessments that require learners to articulate information needs; use resources in digital environments; organize, process, analyze and interpret information; and critically compare and evaluate the credibility and reliability of information and its sources; understanding the academic context and how they can contribute to the scientific community through written production and academic publication.

\section{Results}

According to the project of implementation of this proposal, it is presented, briefly, the characterization and structure of the new curricular unit. 
Table 1. Information Literacy for Academic Writing contents.

\section{Learning objectives}

Incorporate learning activities, tasks, and assessments that require learners to articulate information needs; find information and resources in digital environments; organize, process, analyze and interpret information; and critically compare and evaluate the credibility and reliability of information and its sources; understanding the academic context and how they can contribute to the scientific community through written production and academic publication.

\section{Content}

a. Begin academic work - Develop students' skills around information literacy (skills, dispositions, and attitudes towards information; how and why to get and give back contributions to the scientific community)

b. Search to write - How to choose a topic, what to look for, where to look, how to develop a search strategy, how to find the full text, how to evaluate the information found?

c. Writing ethically - Understand and apply strategies to cite and reference, understand and avoid plagiarism.

d. Construct and publish a scientific article - How to organize and present the information resulting from an investigation, where to publish, what style of writing to use, what to consider before submitting, dealing with rejection of an article, publishing.

e. Understanding the context of Open Science - digital identity, predatory journals, fallacies and dangers in fake news, data sharing, scientific repositories

\section{Teaching and assessment methodologies}

The methodologies used to assess and consolidate knowledge include the exposure of the main concepts in the classroom context. Explanation, reflection, and application of the contents about the research process in resources, selection, and organization of information, articulation, and textual construction, and application of APA norms in the writing. Case studies, with expository and participatory methodologies, will be used.

\section{Demonstration of the coherence of teaching methodologies with the learning objectives of the curricular unit}

The practical classes will be used for close monitoring of the writing process and training of academic skills, particularly in information literacy, using the associated tools. The teaching methodologies will involve the reading of original articles that constitute case studies that can be discussed and worked in groups by the students. To better address the issues under analysis, practical examples will be used to demonstrate the different stages of the processes. 


\section{Discussion and conclusions}

The transdisciplinary nature of information literacy, particularly when coupled with writing in the academic context, allows us to anticipate appropriate practical applicability. Similar to the case studies already analyzed, those by Yevelson-Shorsher \& Bronstein (2018) or Dawes (2019) show that information skills education programs that seek to combine these characteristics seem to be successful. Furthermore, the important collaboration of librarians, underlined by these same studies, has significant advantages in the knowledge of information resources in depth so their experience should be harnessed to build significant insights. Effective information literacy skills are sought through information search to locate, select, retrieve and evaluate information using a variety of sources and tools, distinguishing between academic and non-academic sources, compiling, categorizing and managing citations during the information search process, applying an ethical and legal standard to the use of information, critically evaluating information sources and resources. By promoting the work of systematization and communication of information, the search for sources in various formats, both written and oral, enables us to understand the research process, including the use of error as a learning strategy. By demonstrating dispositions such as the investigative spirit, resilience, and confidence to apply knowledge to new problems and situations, we will be developing skills to safely use technologies in research, and to develop an attitude of trust in problem-solving, valuing student-oriented learning concepts. This case can be used to stimulate reflection and inspiration in the education of higher education teachers, particularly those that seek to facilitate and promote improvements in university students learning', especially concerning information literacy, integrating strategies and tools adapted for the development of information skills.

\section{References}

Association of College \& Research Libraries [ACRL]. (2016). Framework for information literacy for higher education. Chicago, IL: American Library Association. Retrieved from www.ala.org/acrl/standards/ilframework

American Library Association [ALA] (2000). Information Literacy Competency Standards for Higher Education. Association of College and Research Libraries, American Library Association, Chicago: ACRL. Retrieved from: http://www.ala.org/acrl/sites/ala.org.acrl/files/content/standards/standards.pdf

Aramburuzabala, P., Hernández-Castilla, R., Ángel-Uribe, I.C. (2013). Modelos y tendencias de la formación docente universitaria. Profesorado, 17(3), 345-357. Recuperado de: http://hdl.handle.net/10481/30073

Cowan, S., \& Eva, N. C. (2016). Changing our aim: infiltrating faculty with information literacy. Communications in Information Literacy, 10(2), 10. 
Cruz, G., Nascimento, M. M., \& Dominguez, C. (2019). With a little help from my peers: professional development of higher education teachers to teach critical thinking. Revista Lusófona de Educação, 44(44), 141-157.

Dawes, L. (2019). Through Faculty's Eyes: Teaching Threshold Concepts and the Framework. Portal: Libraries and the Academy, 19(1), 127-153.

Esteves, M. (2011, July). Modos de implicação dos professores na docência universitária. In XI Congresso da Sociedade Portuguesa de Ciências da Educação.

Fisher, Z. (2017). Facing the frames: Using the Framework as a guide for a credit-bearing information literacy course. $C \& R L$ News, 78(7), 354-355. Doi: 10.5860/crln.78.7.354

Godbey, S. (2018). Testing Future Teachers: A Quantitative Exploration of Factors Impacting the Information Literacy of Teacher Education Students. College and Research Libraries, 79(5), 611.

Lopes, C., Sanches, T., Andrade, I., Antunes, M., \& Alonso-Arévalo, J. (Eds.). (2016). Literacia da Informação em Contexto Universitário. Lisboa: Edições ISPA. http://hdl.handle.net/10400.12/5067

Maybee, C., Bruce, C. S., Lupton, M., \& Pang, M. F. (2019). Informed learning design: teaching and learning through engagement with information. Higher Education Research \& Development, 38(3), 579-593.

McGill, L. (2017). Transforming curriculum delivery through technology”: JISC Programme Synthesis Report (2011). Retrieved form: http://www.jisc.ac.uk/media/documents/programmes/curriculumdelivery/curriculumdeli veryfinalreport.pdf

Ó, J. R., Almeida, M., Viana, J., Sanches, T., Paz, A. (2019). Tendências recentes da investigação internacional sobre Pedagogia do ensino superior: uma revisão da literatura. Revista Lusófona de Educação, 45, 201-217.

Ödalen, J., Brommesson, D., Erlingsson, G. Ó., Schaffer, J. K., \& Fogelgren, M. (2019). Teaching university teachers to become better teachers: the effects of pedagogical training courses at six Swedish universities. Higher Education Research \& Development, 38(2), 339-353.

Peres, M., Miranda, A., Simeão, E. (2015). Promoção de competências em informação: formação para iniciação científica no ensino superior e comunidades. Revista IberoAmericana de Ciência da Informação, 9, (1) 213-220. DOI https://doi.org/10.26512/rici.v9.n1.2016.2231.

Perzycka, E. (2015). Teacher's learning processes of information competences in the network society: proposed theoretical model and methodological solutions. The New Educational Review, 40(2), 180-188.

Rivilla, A. M. M., Cabezas, A. R., Navío, E. P., \& Domínguez, M. C. M. (2019). Diagnóstico de un programa de formación de docentes en competencias para el primer año de universidad. Aula abierta, 48(2), 239-250.

Sanches, T. (2017). Required Skills for Teachers: Information Literacy at the Top. In European Conference on Information Literacy (pp. 634-644). Springer, Cham.

Swanson, T. (2017). Sharing the ACRL Framework with faculty: Opening campus conversations. C\&RL News, 78(1), 12-4,48. Doi: /10.5860/crln.78.1.9600 
Shipman, T., Bannon, S. H., Nunes-Bufford, K. (2015).The information-seeking habits of inservice educators. College and Research Libraries, 76 (2), 120-135.

Schrum, L., Niederhauser, D. S., Strudler, N. (2016). Competencies, challenges, and changes: a US perspective on preparing twenty-first century teachers and leaders. In J. M. Spector et al. (Eds.), Competencies in teaching, learning and educational leadership in the digital age (pp. 47-56). Springer, Switzerland.

Silva, A. C., Farias, M. G. G. (2019). Competência em informação para a iniciação científica: análise sob a perspectiva dos orientadores. In G. B. Farias, M. G. Farias (Orgs.), Competência e Mediação da Informação: percepções dialógicas entre ambientes abertos e científicos (pp. 52-66). São Paulo: Abecin.

United Nations Educational, Scientific and Cultural Organization [UNESCO] (1997). Recommendation concerning the status of higher education teaching personnel. UNESCO. Retrieved from: http://portal.unesco.org/en/ev.phpURL_ID=13144\&URL_DO=DO_TOPIC\&URL_SECTION=201.html

Yevelson-Shorsher, A., \& Bronstein, J. (2018). Three perspectives on information literacy in academia: talking to librarians, faculty, and students. College \& Research Libraries, 79(4), 535.

Zabalza, M. A. (2007). Competencias docentes del profesorado universitario : calidad y desarrollo profesional. Madrid: Narcea. 